\title{
Psychometric Properties of the Youth Risk Behavior Survey (YRBS) Instrument in Brazilian College Students
}

\author{
Celina Aparecida Gonçalves Lima ${ }^{1}$ (i) \\ Maria de Fatima Matos Maia ${ }^{1}$ (D) \\ Maria Fernanda Santos Figueiredo Brito ${ }^{1}$ \\ Lucineia de Pinho ${ }^{1}$ \\ Marise Fagundes Silveira ${ }^{1}$
}

\begin{abstract}
Considering the importance of health risk behaviors (HRB) and the need for reliable instruments to evaluate them, this study was designed to evaluate the psychometric properties of the items of the Youth Risk Behavior Survey (YRBS) in a sample of 902 college students. Convergent validity, criterion, internal consistency, and temporal stability were evaluated. Higher correlations were observed between use of other drugs and use of marijuana $(\rho=0.537)$, and alcohol consumption and tobacco use $(\rho=0.418)$. Criterion validity was observed, with significant differences between domain scores according to gender. Adequate internal consistency, Cronbach's alpha $=0.770$ for overall scale. Most of the domains $(82 \%)$ showed intraclass correlation coefficient $\geq 0.75$ and $64.1 \%$ of the items showed kappa $\geq 0.60$. The instrument seems to have indicators of criterion validity, internal consistency and temporal stability with satisfactory levels. We recommend that HRB assessment using YRBS should be performed separately on each domain.
\end{abstract}

Keywords: risk behavior, college students, psychometrics

\section{Propriedades Psicométricas do Instrumento Youth Risk Behavior Survey (YRBS) entre Universitários do Brasil}

\begin{abstract}
Resumo: Considerando-se a importância dos comportamentos de risco à saúde (CRS) e a necessidade de instrumentos confiáveis para avaliá-los, este estudo teve como objetivo avaliar as propriedades psicométricas dos itens do Youth Risk Behavior Survey (YRBS) em uma amostra de 902 universitários. Foram avaliadas validade convergente, critério, consistência interna e estabilidade temporal. Observaramse maiores correlações: uso de outras drogas e uso de maconha $(\rho=0,537)$, consumo de bebida alcóolica e uso de tabaco $(\rho=0,418)$. Constatou-se validade de critério, com diferenças significativas entre escores dos domínios segundo o sexo. Consistência interna adequada, alfa de Cronbach $=0,770$ para escala geral. A maioria dos domínios (82\%) apresentou coeficiente de correlação intraclasse $\geq 0,75$ e $64,1 \%$ dos itens apresentaram kappa $\geq 0,60$. O instrumento parece apresentar indicadores de validade de critério, consistência interna e estabilidade temporal com níveis satisfatórios. Recomenda-se que avaliação dos CRS, por meio do YRBS, seja realizada por domínios separadamente.
\end{abstract}

Palavras-chave: comportamento de risco, estudantes universitários, psicometria

\section{Propiedades Psicométricas del Instrumento Youth Risk Behavior Survey (YRBS) entre Estudiantes Universitarios en Brasil}

\begin{abstract}
Resumen: Teniendo en cuenta la importancia de las conductas de riesgo para la salud (CRS) y la necesidad de instrumentos confiables para evaluarlas, este estudio tuvo como objetivo evaluar las propiedades psicométricas de los ítems de la Youth Risk Behavior Survey (YRBS) en una muestra de 902 estudiantes universitarios. Se evaluaron la validez convergente, el criterio, la consistencia interna y la estabilidad temporal. Se observaron correlaciones más altas para: uso de otras drogas y uso de marihuana $(\rho=0.537)$, consumo de alcohol y uso de tabaco $(\rho=0.418)$. Se verificó la validez del criterio, con diferencias significativas entre las puntuaciones de dominio según el género. Consistencia interna adecuada, alfa de Cronbach $=0.770$ para la escala general. La mayoría de los dominios (82\%) presentó un coeficiente de correlación intraclase $\geq 0.75$ y el $64.1 \%$ de los ítems presentaron kappa $\geq 0.60$. El instrumento parece presentar indicadores de validez de criterio, consistencia interna y estabilidad temporal con niveles satisfactorios. Se recomienda que la evaluación de CRS a través de YRBS sea realizada por dominios por separado.
\end{abstract}

Palabras clave: conducta de riesgo, estudiantes universitarios, psicometría

${ }^{1}$ Universidade Estadual de Montes Claros, Montes Claros-MG, Brazil

This article is based on the master's thesis of the first author under the supervision of the fifth author, presented in 2017 at the Graduate Program of Health Sciences, Universidade Estadual de Montes Claros.

Correspondence address: Celina Aparecida Gonçalves Lima. Universidade Estadual de Montes Claros. Departamento de Ciências Exatas e Tecnológicas. Av. Dr. Rui Braga, s/n., vila Mauriceia. Montes Claros-MG, Brazil. CEP 39.401-089. E-mail: celina.prof@bol.com.br
Health-related risk behaviors (HRB) are common among young people (Arroyave et al., 2016) and are considered potentially harmful (Alves, Zappe, \& Dell'aglio, 2015), requiring research and surveillance (Brener et al. al., 2013; Currie et al., 2008; World Health Organization [WHO], 2009). Studies have evaluated these behaviors in international (Eaton et al., 2012; Hidalgo-Rasmussen, Hidalgo-San 
Martin, Rasmussen-Cruz, \& Montano-Espinoza, 2011; Wang et al., 2012) and national (Bernardelli Junior, 2010; Faria, Gandolfi, \& Moura, 2014; Gasparotto, Legnani, Legnani, \& Campos, 2015; Malta, Mascarenhas, Porto, Barreto, \& Morais Neto, 2014) scenarios.

In Brazil, HRB in young people have high prevalences. Frequent alcohol abuse was observed in $18.2 \%$ in the 18 24 years age group (Ministério da Saúde, 2014) and in $75 \%$ of college students (Campos, Isensse, Rucker, \& Bottan, 2016). Alcohol intake before driving was reported by $39.2 \%$ of college students (Mesquita Filho, Carvalho, \& Garcia, 2017). The prevalence of illicit drug use was $15.8 \%$ in students aged 13-19 years (Raposo et al., 2017). The prevalence of sexual practice without condom use was $71 \%$ in Brazilian college students (Oliveira et al., 2013). Gender differences in risk behaviors were found (Mola et al., 2017; Oliveira-Campos et al., 2014; Raposo et al., 2017).

HRB can interrelate with each other and have common antecedents, which contributes to their associated occurrence (Guedes \& Lopes, 2010; Mola et al., 2017; Raposo et al., 2017). Nevertheless, these behaviors are usually assessed in isolation (Wang et al., 2012) through elaborate questionnaires, based on adaptations of various instruments, which may compromise quality and the possibility to compare studies (Guedes \& Lopes, 2010). Thus, it is recommended to study several risk behaviors together (Guedes \& Lopes, 2010; Wang et al., 2012).

Instruments that evaluate health risk behaviors simultaneously are scarce in the Brazilian literature (Guedes \& Lopes, 2010). One of the instruments used to assess youth health risk behaviors is the Youth Risk Behavior Survey (YRBS).

The YRBS is an appropriate tool for measuring multiple risk health behaviors in young people (Santos Silva \& Menezes, 2010). This instrument was created by the Centers for Disease Control and Prevention (CDC) in the United States in the 1980s. It focuses on risky behaviors that develop during youth and result in mortality, morbidity, social problems, complications, and behavioral problems at this stage and into adulthood (Brener et al., 2002). The YRBS is a good indicator to capture the behaviors that contribute to unintentional injuries and violence, tobacco use, alcohol use and other drug use, sexual behaviors that contribute to unintended pregnancy and sexually transmitted diseases, poor eating habits and physical activity among young people (Brener et al., 2002; Eaton et al., 2012; Guedes \& Lopes, 2010; Kann et al., 2016).

YRBS has been translated and validated in several countries, such as Portugal (Santos et al., 2010), China (Wang et al., 2012) and Persia (Baheiraei et al ., 2012) with satisfactory instrument quality indices. In Brazil, YRBS for adolescents was translated and adapted cross-culturally by Guedes and Lopes in 2010. Regarding the psychometric quality of the instrument, these authors observed that $91.0 \%$ of its items had moderate to substantial kappa agreement index, demonstrating adequate test-retest reliability (Guedes \& Lopes, 2010). In 2008, YRBS for college students was also translated and adapted in Brazil by Dartagnan Pinto Guedes's team (Teixeira, 2009). In their study, the kappa agreement index ranged from $61 \%$ to $99 \%$, substantial to excellent. The presence of temporal stability of the items on risk behavior of the Youth Risk Behavior Survey questionnaire is necessary, since young people may experience changes in behavior over time (Guedes \& Lopes 2010).

Previous studies have also demonstrated adequate psychometric properties for a variety of self-reported risk behaviors among young people (Brener et al., 2002; Rosenbaum, 2009). However, an instrument may have satisfactory levels of these properties in a population, but a different performance when applied to subjects with distinct characteristics from the reference population (Keszei, Novak, $\&$ Streiner, 2010). Considering that inaccurate data can lead to errors in identifying risk behaviors and therefore in policy formulation and assessment of target group interventions (Rosenbaum, 2009), this study was designed to evaluate the psychometric properties of the risk behavior items of the Youth Risk Behavior Survey (YRBS) in college students from a public institution in northern Minas Gerais, Brazil.

\section{Method}

\section{Participants}

This study is part of the epidemiological study Health risk behaviors of college students at Universidade Estadual de Montes Claros (UNIMONTES). The study population consisted of 7,868 students from UNIMONTES, a public university located in the north of the state of Minas Gerais, in various undergraduate courses in the area of Humanities, Biological and Health Sciences, Exact and Technological Sciences, and Social and Applied Sciences in 2013.

The sample size was defined based on the following parameters: expected HRB prevalence of $50 \%$, confidence level of $95 \%$ and margin of error of $5 \%$. After correcting for design effect $($ deff $=2)$ and a $20 \%$ addition for non-response rate, a minimum required sample of 960 individuals was determined (Luiz \& Magnanini, 2000). The number of college students previously defined for participation in the population-based study met the assumptions for sample size in a psychometric validation study, which, according to Hair, Anderson, Tatham and Black (2005), should be of at least 300 individuals.

For sample selection, two-stage cluster probabilistic sampling was adopted. In the first stage, $50 \%$ of the courses were selected by simple random sampling (SRS) and, in the second stage, also by SRS, $25 \%$ of the classes of each selected course.

In total, 902 students participated in the study, $605(67.1 \%)$ were female and $507(56.2 \%)$ were 21 years old or younger. Of these, $184(20.4 \%)$ were enrolled in health courses, $144(16.0 \%)$ in STEM ones, 327 (36.2\%) in humanities programs, and 247 $(27.4 \%)$ in social courses. For the test-retest, 110 students from five undergraduate courses participated: Administration (19.1\%), Economic Sciences (15.5\%), Physical Education Bachelor's degree (23.6\%), Physical Education Teaching Degree (19.1\%), and Civil Engineering (22.7\%). 


\section{Instruments}

Questionnaire for Student Characterization. Instrument composed of sociodemographic (gender and age) and academic (undergraduate area: biological and health, STEM, social and humanities) variables.

Youth Risk Behavior Survey (YRBS). An instrument created by the Centers for Disease Control and Prevention CDC, in the United States in the 1980s. In Brazil it was translated and cross-culturally adapted in 2008 (Teixeira, 2009). The instrument contains 78 HRB-related items, composed of multiple-choice questions, where the interviewee selects the option that best matches the situations they experience. Response options are dichotomous (10 items) or ordinal polytomous (66 items) that express the frequency of HRB in different time frames (previous day, past seven days, past 30 days, past 12 months or during life). In addition to these items, YRBS has two open questions about the respondent's weight and height. Items are distributed over 11 domains: personal safety (ten items); violence (five items); suicide (four items); tobacco use (eight items); alcohol consumption (three items); cannabis use (three items); other drug use (ten items); sexual activity (fifteen items); body weight (eight items); feeding (seven items); physical activity (five items) (Bernardelli Junior, 2010; Eaton et al., 2012; Guedes \& Lopes, 2010).

\section{Procedure}

Data collection. Data were collected in the classroom by trained staff and under the supervision of the researchers responsible for the project. The students who were present at the time of administering the instrument were invited to participate in the research. Before answering the instrument, students were informed about the study objectives and preservation of anonymity. For the test-retest, the instrument was administered and re-administered at a 15-day interval in a sample of 110 students. During the first administration a draw was made of the numbers to identify the students who were present; they then received a copy of the instrument, which was identified by the number drawn. Upon completion, students deposited the instrument in a sealed envelope. In the second administration, the students identified their replica with the same number drawn previously and filled it out following the same instructions.

Data analysis. Student characterization regarding demographic variables (gender, age group, undergraduate area) and risk behavior was performed through frequency distribution. The psychometric properties of the risk behavior items of the Youth Risk Behavior Survey (YRBS) evaluated were convergent validity, criterion validity and reliability (internal consistency and temporal stability). To this end, the response options of each item on risk behaviors were associated with a numerical value (Likert scale), and the higher this value, the more frequent the HRB analyzed by the item. The scores of each domain of the instrument were also calculated, corresponding to the average of its items, and the higher the score, the higher the HRB. Table 1 shows the variations (minimum and maximum values) of the scores in the 11 domains.

Convergent validity was assessed by the correlations between instrument domains (Maroco, 2010). For this, the Spearman correlation coefficient was adopted, since normal distribution of items and domain scores was absent (Kolmogorov-Smirnov test). The presence of correlation was considered as the significance level $p<0.05$. For criterion validity, domain scores were compared between subgroups, defined according to student gender, which hypothetically should exhibit different levels of risk behavior (Faria et al., 2014; Loch, Bortoletto, Souza, \& Mesas, 2015). For this, the Mann-Whitney test was used, at a significance level of 0.05 . Cohen's $d$ effect size was used as well, ranging from zero to infinity, being insignificant $(d<0.19)$, small $(d=0.20$ to $0.49)$, medium $(d=0.50$ to 0.79$)$, large $(d=0.80$ to 1.29$)$ and very large $(d>1.30)$ (Cohen, 1988; Lakens, 2013).

Internal consistency was assessed by Cronbach's alpha coefficient for the overall scale (all items) and for each domain. The minimum value adopted for satisfactory internal consistency was 0.70 (Hair, Black, Babin, Anderson, \& Tatham, 2006). In the internal consistency analysis, the use of Cronbach's alpha is considered a limitation on scales with heterogeneous and dichotomous items, which may provide an underestimate of the true reliability of the measurement (Maroco, 2010; Maroco \& Garcia-Marques, 2006). For scales with these characteristics, the use of Kuder-Richardson (KR21) is suggested. However, in this study it was not possible to use it due to the specificities of YRBS, which has most dimensions with polytomous and some dichotomous items.

To assess the temporal stability of YRBS risk behavior items, a test-retest was performed on 110 students, meeting the minimum recommendation of $10 \%$ of the sample (Shrout \& Fleiss, 1979). To estimate the agreement between the responses at the two moments, the Kappa coefficient was calculated for all items of the instrument, adopting the following interpretation: no agreement $(<0)$, poor agreement (0 to 0.19$)$, fair agreement $(0.20$ to 0.39$)$, moderate agreement (0.40 to 0.59$)$, substantial agreement $(0.60$ to 0.79$)$, and excellent agreement (0.80 to 1.0$)$ (Landis \& Koch, 1977) The scores of each domain (mean of the items) in the two evaluated moments were calculated as well, whose level of agreement was analyzed using the intraclass correlation coefficient (ICC). For ICC interpretation the following scale was adopted: poor $(<0.40)$, satisfactory $(0.40 \leq \mathrm{ICC}<0.75)$ and excellent $(\geq 0.75)$ (Shrout \& Fleiss, 1979). All statistical analyses were performed using Predictive Analytics Software $(\text { PASW })^{\circledR}$, version 19.0 for Windows ${ }^{\circledR}$.

\section{Ethical Considerations}

The study was approved by the Research Ethics Committee of Universidade Estadual de Montes Claros (Opinion No. 30679/2012) and all the college students who agreed to participate signed an Informed Consent Form. 


\section{Results}

The prevalence of HRB ranged from $1.6 \%$ to $87.7 \%$, and the most frequent behaviors were: alcohol consumption (45.7\%), no condom use during past 30 days $(63.1 \%)$, and low fruit consumption (87.7\%); the behaviors with the lowest values were: daily smoking $(1.7 \%)$ and low consumption of green salads and cooked vegetables $(1.6 \%)$.

Table 1 shows the results of convergent validity. Across domains, the highest significant correlations observed were: other drug use and cannabis use $(\rho=0.54 ; p=0.000)$, alcohol consumption and tobacco use $(\rho=0.42 ; p=0.000)$, marijuana use and tobacco use ( $\rho=0.41 ; p=0.000)$, sexual activity and alcohol consumption $(\rho=0.36 ; p=0.000)$, other drug use and tobacco use $(\rho=0.36 ; p=0.000)$, and sexual activity and tobacco use $(\rho=0.32, p=0.000)$.

Comparisons between domain scores by gender are shown in Table 1. Significant gender differences $(p \leq 0.05)$ were found in most YRBS domains, except in the suicide intent and feeding domains, suggesting criterion validity of the instrument.

Regarding effect size, the highest rates were for tobacco use $(d=1.92)$, personal safety $(d=0.50)$ and sexual activity $(d=0.50)$ (Table 1).

The internal consistency measure of the YRBS risk behavior items presented Cronbach's alpha coefficients equal to 0.77 for the general scale. For the domains, Cronbach's alpha coefficient ranged from 0.11 (body weight) to 0.78 (sexual activity) (Table 2).

Table 1

Convergent validity, mean (M), and standard deviation (SD) of domain scores by gender of the Youth Risk Behavior Survey (YRBS) instrument

\begin{tabular}{|c|c|c|c|c|c|c|c|c|c|c|c|}
\hline \multicolumn{4}{|c|}{ Domain } & \multicolumn{2}{|c|}{$\begin{array}{l}\text { Scale Range } \\
\text { (Min. - Max.) }\end{array}$} & \multicolumn{2}{|c|}{$\begin{array}{l}\text { Female } \\
(\mathrm{M} \pm \mathrm{SD})\end{array}$} & \multicolumn{2}{|c|}{$\begin{array}{c}\text { Male } \\
(\mathrm{M} \pm \mathrm{SD})\end{array}$} & P-value & Cohen's d Index \\
\hline \multicolumn{4}{|c|}{ Personal safety (PS) } & \multicolumn{2}{|c|}{$(0-5)$} & \multicolumn{2}{|c|}{$1.40 \pm 0.48$} & \multicolumn{2}{|c|}{$1.65 \pm 0.53$} & $0.000 *$ & 0.50 \\
\hline \multicolumn{4}{|c|}{ Violence (V) } & \multicolumn{2}{|c|}{$(0-8)$} & \multicolumn{2}{|c|}{$0.85 \pm 0.21$} & \multicolumn{2}{|c|}{$0.88 \pm 0.28$} & $0.049 *$ & 0.14 \\
\hline \multicolumn{4}{|c|}{ Suicide intent (SI) } & \multicolumn{2}{|c|}{$(0-5)$} & \multicolumn{2}{|c|}{$0.84 \pm 0.23$} & \multicolumn{2}{|c|}{$0.82 \pm 0.16$} & 0.804 & 0.10 \\
\hline \multicolumn{4}{|c|}{ Tobacco use (TU) } & \multicolumn{2}{|c|}{$(0-7)$} & \multicolumn{2}{|c|}{$0.90 \pm 0.37$} & \multicolumn{2}{|c|}{$1.06 \pm 0.55$} & $0.000 *$ & 1.92 \\
\hline \multicolumn{4}{|c|}{ Alcoholic drink consumption (ADC) } & \multicolumn{2}{|c|}{$(0-7)$} & \multicolumn{2}{|c|}{$2.25 \pm 1.28$} & \multicolumn{2}{|c|}{$2.73 \pm 1.42$} & $0.000 *$ & 0.37 \\
\hline \multicolumn{4}{|c|}{ Marijuana use (MU) } & \multicolumn{2}{|c|}{$(0-7)$} & \multicolumn{2}{|c|}{$0.74 \pm 0.40$} & \multicolumn{2}{|c|}{$0.96 \pm 0.90$} & $0.000 *$ & 0.36 \\
\hline \multicolumn{4}{|c|}{ Other drug use (ODU) } & \multicolumn{2}{|c|}{$(0-7)$} & \multicolumn{2}{|c|}{$0.92 \pm 0.10$} & 0.95 & 0.23 & $0.001 *$ & 0.20 \\
\hline Sexual & tivity (S & & & $(0-$ & & $1.12=$ & 0.65 & 1.44 & 0.63 & $0.000 *$ & 0.50 \\
\hline Body v & ght (BW & & & $(1-$ & & 2.06 & 0.30 & 2.08 & 0.26 & 0.482 & 0.07 \\
\hline Feedin & & & & $(1-$ & & $2.41=$ & 0.38 & 2.39 & 0.39 & 0.314 & 0.06 \\
\hline Physic: & activity ( & & & $(1-$ & & $6.0=$ & 1.24 & 5.57 & 1.52 & $0.000 *$ & 0.32 \\
\hline & PS & $\mathrm{V}$ & SI & $\mathrm{TU}$ & $\mathrm{ADC}$ & MU & ODU & AT & $\mathrm{BW}$ & $\mathrm{F}$ & $\mathrm{PA}$ \\
\hline PS & 1 & & & & & & & & & & \\
\hline $\mathrm{V}$ & $0.11 *$ & 1 & & & & & & & & & \\
\hline SI & 0.06 & $0.16 *$ & 1 & & & & & & & & \\
\hline TU & $0.10 *$ & $0.19 *$ & $0.12 *$ & 1 & & & & & & & \\
\hline $\mathrm{ADC}$ & $0.26 *$ & $0.20 *$ & $0.13 *$ & $0.42 *$ & 1 & & & & & & \\
\hline MU & $0.08 *$ & $0.15 *$ & $0.15 *$ & $0.41 *$ & $\begin{array}{c}0.26 \\
*\end{array}$ & 1 & & & & & \\
\hline ODU & $0.07 *$ & $0.15 *$ & $0.08 *$ & $0.36 *$ & $\begin{array}{c}0.26 \\
*\end{array}$ & $0.54 *$ & 1 & & & & \\
\hline SA & $0.26 *$ & $0.16 *$ & $0.07 *$ & $0.32 *$ & $\begin{array}{c}0.36 \\
*\end{array}$ & $0.20 *$ & $0.18 *$ & 1 & & & \\
\hline BW & $-0.08 *$ & $-0.11 *$ & $\begin{array}{c}-0.08 \\
*\end{array}$ & $-0.08 *$ & $\begin{array}{c}-0.11 \\
*\end{array}$ & $-0.05 *$ & $\begin{array}{c}-0.10 \\
*\end{array}$ & -0.06 & 1 & & \\
\hline $\mathrm{F}$ & $0.11 *$ & 0.05 & -0.03 & 0.04 & $\begin{array}{c}0.11 \\
*\end{array}$ & 0.02 & 0.02 & -0.01 & $0.10 *$ & 1 & \\
\hline $\mathrm{PA}$ & $-0.12 *$ & -0.05 & -0.04 & 0.01 & -0.02 & -0.04 & -0.06 & -0.06 & $0.21 *$ & $0.13 *$ & 1 \\
\hline
\end{tabular}

Note. $\mathrm{SP}=$ Personal safety $; \mathrm{V}=$ Violence; $\mathrm{SI}=$ Suicide intent $\mathrm{TU}=$ Tobacco use; $\mathrm{ADC}=$ Alcoholic drink consumption; $\mathrm{MU}=\mathrm{Marijuana}$ use; ODU = Other drug use; SA = Sexual activity; A = Feeding; PA = Physical activity; *significant. 
Table 2

Internal consistency analysis and intraclass correlation coefficient (ICC) of the Youth Risk Behavior Survey (YRBS) domains

\begin{tabular}{lcc}
\hline Domain & Cronbach's Alpha & CCI \\
\hline Personal safety & 0.44 & 0.86 \\
Violence & 0.45 & 0.55 \\
Suicide intent & 0.70 & 0.26 \\
Tobacco use & 0.60 & 0.94 \\
Alcoholic drink & 0.66 & 0.95 \\
consumption & 0.77 & 0.94 \\
Marijuana use & 0.71 & 0.87 \\
Other drug use & 0.78 & 0.98 \\
Sexual activity & 0.11 & 0.77 \\
Body weight & 0.42 & 0.80 \\
Feeding & 0.70 & 0.85 \\
Physical activity & 0.77 & - \\
Overall scale & & \\
\hline
\end{tabular}

Regarding temporal stability, most domains showed excellent agreement (ICC $\geq 0.75$ ), except for the violence $(\mathrm{ICC}=0.55)$ and suicide $(\mathrm{ICC}=0.26)$ domains (Table 2).

Kappa coefficient results showed that $64.1 \%$ of the items had at least substantial agreement (kappa $\geq 0.60$ ) and $83.3 \%$ had at least moderate agreement (kappa $\geq 0.40)$ (Appendix 1).

\section{Discussion}

This study evaluated the evidence of validity and reliability of the YRBS instrument items that identify youth health risk behaviors, in a student population at a public university located in the north of the state of Minas Gerais. In the national literature, no previous studies that jointly evaluated the evidence of YRBS validity and reliability were identified.

Young people often have health risk behaviors in their daily lives (Eaton et al., 2012; Faria et al., 2014; Gasparotto et al., 2015; Malta et al., 2014; Wang et al., 2012), as seen in this study, the most prevalent being alcohol consumption, non-use of condoms in sexual relations and low consumption of fruits.

Gathering information about health risk behaviors in this age group through the use of validated instruments is necessary to obtain data that adequately assess the measured construct (Guedes \& Lopes, 2010). The quality of the results obtained is essential to support the planning and implementation of public policies and appropriate intervention strategies aimed at promoting and protecting health among young people (Brito, Hardman, \& Barros, 2015).

The items on risk behaviors of the YRBS instrument showed criterion validity, internal consistency and temporal stability. Regarding criterion validity, YRBS risk behaviors items proved to be effective in distinguishing the different levels of health risk behavior by gender. Male students had higher levels of HRB related to personal safety, violence, tobacco use, alcohol consumption, marijuana use, other drugs, and sexual activity. Previous studies evaluating HRB in young people demonstrated gender differences in these behaviors (Eckschmidt, Andrade, \& Oliveira, 2013; Elicker et al., 2015; Faria et al., 2014). Males are more likely to display HRB due to social influence and cultural factors of demonstration of power (Antoniassi Júnior \& Gaya, 2015). In addition, they are more susceptible to tobacco use and alcohol abuse (Loch et al., 2015).

Regarding internal consistency, the items on risk behaviors of the instrument had satisfactory Cronbach's alpha coefficient for the overall scale. A study conducted on a sample of 392 college students showed higher values for this coefficient (Teixeira, 2009). In the analysis of internal consistency by domain, most showed adequate values. The domains personal safety, violence, weight and feeding had lower internal consistency indices, which may be related to the fact that the items that make up these domains address different situations, which may probably interfere with the results. This result may be associated with the assumption that these behaviors are temporary states rather than stable traces.

In the analysis of temporal stability, the instrument showed a satisfactory result for intraclass correlation coefficient in all domains except the suicide intent domain. Kappa agreement coefficient was substantial or excellent in most items on risk behaviors of the YRBS instrument. This result is lower than that reported in previous studies conducted with adolescents (Guedes \& Lopes, 2010; Zullig, Pun, Patton, \& Ubbes, 2006) and university students (Teixeira, 2009). This coefficient was higher than that reported by Brener et al. (2002) in a study with adolescents

The items related to suicide attempt, use of tobacco, alcohol, marijuana and other drugs, sexual behavior and personal safety demonstrated greater temporal stability than those related to eating behaviors and physical activity. Similar results were found in the study with an international sample of 4,619 high school students (Brener et al., 2002). Probably, higher indicators of temporal stability were observed in these items because they are considered of greater importance among young people (Guedes \& Lopes, 2010). Among young people, behaviors related to the use of substances such as tobacco, alcohol and drugs, sexual activity and behaviors that involve rebellion, such as dangerous driving and violence, are more present and, therefore, the items of these dimensions stood out in the instrument with the highest Kappa coefficient (Guedes \& Lopes, 2010).

Another aspect of the YRBS risk behavior items that may have interfered with the Kappa agreement coefficient is the response options with different time frequencies ("previous day", "past seven days", "past 30 days", "past 12 months", or "during life"). Kappa values varied for different time intervals. Possibly, the reference period of the item may interfere with the responses of young people and, therefore, affect agreement (Guedes \& Lopes, 2010). This fact should be taken into account, as low kappa coefficient values may reflect a change in behavior within the 15 days between the two administrations of the instrument (Guedes \& Lopes, 2010). 
Regarding convergent validity, assessed by analysis of inter-domain correlations, a significant correlation between all domains was expected, if we consider that individuals may present simultaneous risk behaviors and any negative behavior may associate with others (Loch et al., 2015). We highlight the correlations found in this study between the domains other drug use, cannabis use, alcohol consumption, tobacco use, and sexual activity. College time is a period when young people often seek autonomy, new experiences, and new friendships, which may favor student exposure to these risky behaviors (Antoniassi Júnior \& Gaya, 2015; Baumgarten, Gomes, \& Fonseca, 2012; Fachini, 2013; Silva \& Tucci, 2016).

The results obtained from inter-domain correlations in convergent validity in this study suggest that the youngsters surveyed may present risk behavior in one domain and not in others, which may be explained due to the risk behavior construct representing different conjunctures. Such fact reinforces the importance of analyzing the answers of this instrument by domain separately and not by an overall score. Some studies using YRBS evaluated domains separately (Faria et al., 2014; Gasparotto et al., 2015).

The results of this study should be interpreted considering some limitations. YRBS is a self-report instrument with intimate questions, which can influence the accuracy of answers, as participants may lie or omit important information due to privacy concerns (Sales et al., 2016). The excessive number of items in the instrument may discourage students from responding reliably. The instrument items have different variations of the likert scale in response options, besides different temporal frequencies (Guedes $\&$ Lopes, 2010). There is a small percentage of dichotomous items, which makes data analysis difficult.

In this study it was not possible to perform confirmatory factor analysis (CFA) of the risk behavior items of the YBRS instrument, since it is complex due to the large number of items and dimensions that make up the instrument. In addition, some YRBS items are dichotomous and not in ordinal scale, with at least four categories. Another reason for not conducting CFA was the existence of dimensions such as sexual activity - composed of 15 items - that have broad approach themes that could characterize sub-dimensions.

Risk behaviors may be influenced by social, cultural and regional issues, which requires validation of the YBRS instrument. Each population may have a distinct profile of risk behaviors and value them according to their peculiarities. Using an instrument validated for the study population makes it possible to capture these behaviors more accurately and reliably and thus support preventive measures and specific interventions.

We conclude that the risk behavior items of the YRBS instrument showed discriminant validity, internal consistency and temporal stability in college students from the north of Minas Gerais. The assessment of health risk behaviors through the YRBS instrument should be performed by domains separately. Future studies could evaluate the internal structure of the instrument through confirmatory factor analysis.

\section{References}

Alves, C. F., Zappe, J. G., \& Dell'Aglio, D. D. (2015). Índice de Comportamentos de Risco: Construção e análise das propriedades psicométricas [Risky Behavior Index: Construction and analysis of psychometric properties]. Estudos de Psicologia (Campinas), 32(3), 371-382. doi:10.1590/0103-166X2015000300003

Antoniassi Júnior, G., \& Gaya, C. M. (2015). Implicações do uso de álcool, tabaco e outras drogas na vida do universitário [Implications of the use of alcohol, tobacco and other drugs in the university student's life]. Revista Brasileira em Promoção da Saúde, 28(1), 67-74. Retrieved from http://www.redalyc.org/pdf/408/40842428009.pdf

Arroyave, L. J. O., Restrepo-Méndez, M. C., Horta, B. L., Menezes, A. M. B., Gigante, D. P., \& Gonçalves, H. (2016). Tendências e desigualdades nos comportamentos de risco em adolescentes: Comparação das coortes de nascimentos de Pelotas, Rio Grande do Sul, Brasil [Trends and inequalities in risk behaviors among adolescents: A comparison of birth cohorts in Pelotas, Rio Grande do Sul State, Brazil]. Cadernos de Saúde Pública, 32(9), e00120215. doi:10.1590/0102-311x00120215

Baheiraei, A., Hamzehgardeshi, Z., Mohammadi, M. R., Nedjat, S., \& Mohammadi, E. (2012). Psychometric properties of the Persian version of the Youth Risk Behavior Survey Questionnaire. Iranian Red Crescent Medical Journal, 14(6), 363-370. Retrieved from https://www.ncbi.nlm.nih.gov/pmc/articles/PMC3420027/

Baumgarten, L. Z., Gomes, V. L. O., \& Fonseca, A. D. (2012). Consumo alcoólico entre universitários(as) da área da saúde da Universidade Federal do Rio Grande/RS: Subsídios para enfermagem [Alcohol consumption among university students in the health area of Federal University of Rio Grande/RS: Subsidy to the nursing]. Escola Anna Nery, 16(3), 530-535. doi:10.1590/S1414-81452012000300015

Bernardelli Junior, R. (2010). Comportamentos de risco para a saúde de estudantes da Universidade Estadual do Norte do Paraná, Brasil [Risk behavior for the health of students at the State University of North Paraná, Brazil] (Unpublished doctoral dissertation). Universidade Trásos-Montes e Alto Douro, Vila Real, Portugal.

Brener, N. D., Kann, L., McManus T., Kinchen, S. A., Sundberg, E. C., \& Ross, J. G. (2002). Reliability of the 1999 Youth Risk Behavior Survey Questionnaire. Journal of Adolescent Health, 31(4), 336-342. doi:10.1016/ s1054-139x(02)00339-7

Brener, N. D., Kann, L., Shanklin, S., Kinchen, S., Eaton, D. K., Hawkins, J., ... Centers for Disease Control and Prevention. (2013). Methodology of the youth risk behavior surveillance system - 2013. Morbidity and Mortality Weekly Report. Recommendations and Reports, 62(RR-1), 1-20. Retrieved from https://www.cdc.gov/ $\mathrm{mmwr} / \mathrm{preview} / \mathrm{mmwrhtml} / \mathrm{rr} 6201 \mathrm{a} 1 . \mathrm{htm}$ 
Brito, A. L. S., Hardman, C. M., \& Barros, M. V. G. (2015). Prevalence and factors associated with the co-occurrence of health risk behaviors in adolescents. Revista Paulista de Pediatria, 33(4), 423-430. doi:10.1016/j.rpped.2015.02.002

Cohen, J. (1988). Statistical power analysis for the behavioral sciences (2nd ed.). Hillsdale, NJ: Lawrence Erlbaum.

Campos, L., Isensse, D. C., Rucker, T. C., \& Bottan, E. R. (2016). Condutas de saúde de universitários ingressantes e concluintes de cursos da área da saúde [Health conducts of university students and graduates of courses in the health área]. Revista Brasileira de Pesquisa em Saude, 18(2), 17-25. doi:10.21722/rbps.v18i2.15080

Currie, C., Gabhainn, S. N., Godeau, E., Roberts, C., Smith, R., Currie, D., ... Barnekow, V. (Eds.). (2008). Inequalities in young people's health: Health Behaviour in SchoolAged Children (HBSC) international report: From the 2005/2006 survey. Copenhagen, Denmark: WHO Regional Office for Europe. Retrieved from http://www.euro.who. int/__data/assets/pdf_file/0005/53852/E91416.pdf

Eaton, D. K., Kann, L., Kinchen, S., Shanklin, S., Flint, K. H., Hawkins, J., ... Centers for Disease Control and Prevention. (2012). Youth risk behavior surveillance United States, 2011. Morbidity and Mortality Weekly Report. Surveillance Summaries, 61(4), 1-162. Retrieved from http://www.ncbi.nlm.nih.gov/pubmed/22673000

Eckschmidt, F., Andrade, A. G., \& Oliveira, L. G. (2013). Comparação do uso de drogas entre universitários brasileiros, norte-americanos e jovens da população geral brasileira [Comparison of drug use between Brazilian and American college students and Young Brazilian general population]. Jornal Brasileiro de Psiquiatria, 62(3), 199-207. doi:10.1590/S0047-20852013000300004

Elicker, E., Palazzo, L. S., Aerts, D. R. G. C., Alves, G. G., \& Câmara, S. (2015). Use of alcohol, tobacco and other drugs by adolescent students from Porto Velho-RO, Brazil. Epidemiologia e Serviços de Saúde, 24(3), 399410. doi:10.5123/S1679-49742015000300006

Fachini, A. (2013). Aspectos da vida acadêmica associados ao uso de álcool e outras drogas [Aspects of academic life associated with the use of alcohol and others drugs] (Doctoral dissertation). Retrieved from http:/www.teses.usp.br/teses/ disponiveis/17/17148/tde-22102013-141513/es.php

Faria, Y. O., Gandolfi, L., \& Moura, L. B. A. (2014). Prevalence of risk behaviors in young university students. Acta Paulista de Enfermagem, 27(6), 591-595. doi:10.1590/1982-0194201400096

Gasparotto, G. S., Legnani, E., Legnani, R. F. S., \& Campos, C. (2015). Simultaneidade de fatores de risco cardiovascular em universitários: Prevalência e comparação entre períodos de graduação [Simultaneity of cardiovascular risk factors in university students: Prevalence and comparison between graduation periods]. Saúde (Santa Maria), 41(1), 185-194. doi: $10.5902 / 2236583414942$
Guedes, D. P., \& Lopes, C. C. (2010). Validation of the Brazilian version of the 2007 Youth Risk Behavior Survey. Revista de Saúde Pública, 44(5), 840-850. doi:10.1590/s0034-89102010000500009

Hair, J. F., Jr., Anderson, R. E., Tatham, R. L., \& Black, W. C. (2005). Análise multivariada de dados [Multivariate data analysis] (A. S. Sant'Anna \& A. Chaves Neto, Trans., 5th ed.). Porto Alegre, RS: Bookman.

Hair, J. F., Jr., Black, W., Babin, B., Anderson, R. E., \& Tatham, R. L. (2006). Multivariate data analysis (6th ed.). London, United Kingdom: Pearson Educational.

Hidalgo-Rasmussen, C.A., Hidalgo-San Martin, A., RasmussenCruz, B., \& Montano-Espinoza, R. (2011). Calidad de vida, según percepción y comportamientos de control del peso por género, en estudiantes universitarios adolescentes en México [Quality of life, according to perception and behaviors of weight control by gender, in adolescent university students in Mexico]. Cadernos de Saúde Pública, 27(1), 67-77. doi:10.1590/S0102-311X2011000100007

Kann, L., McManus, T., Harris, W. A., Shanklin, S. L., Flint, K. H., Hawkins, J., ... Zaza, S. (2016). Youth Risk Behavior Surveillance - United States, 2015. Morbidity and Mortality Weekly Report. Surveillance Summaries, 65(6), 1-174. doi:10.15585/mmwr.ss6506a1

Keszei, A. P., Novak, M., \& Streiner, D. L. (2010). Introduction to health measurement scales. Journal of Psychosomatic Research, 68(4), 319-323. doi:10.1016/j. jpsychores.2010.01.006

Lakens, D. (2013). Calculating and reporting effect sizes to facilitate cumulative science: A practical primer for t-tests and ANOVAs. Frontiers in Psychology, 4, 863. doi:10.3389/fpsyg.2013.00863

Landis, J. R., \& Koch, G. G. (1977). The measurement of observer agreement for categorical data. Biometrics, 33(1), 159-174. doi:10.2307/2529310

Loch, M. R., Bortoletto, M. S. S., Souza, R. K. T., \& Mesas, A. E. (2015). Simultaneidade de comportamentos de risco para a saúde e fatores associados em estudo de base populacional [Simultaneity of health risk behaviors and associated factors in a population-based study]. Cadernos de Saúde Coletiva, 23(2), 180-187. doi:10.1590/1414462X201500020045

Luiz, R. R., \& Magnanini, M. M. F. (2000). A lógica da determinação do tamanho da amostra em investigações epidemiológicas [The logic of sample size determining in epidemiological research]. Cadernos Saúde Coletiva, 8(2), 9-28. Retrieved from https://edisciplinas.usp. br/pluginfile.php/4116370/mod_resource/content/1/ Determinac\%CC\%A7a\%CC\%83oamostraRonir2000_2.pdf 
Malta, D. C., Mascarenhas, M. D. M., Porto, D. L., Barreto, S. M., \& Morais Neto, O. L. (2014). Exposure to alcohol among adolescent students and associated factors. Revista de Saúde Pública, 48(1), 52-62. doi:10.1590/ S0034-8910.2014048004563

Maroco, J. (2010). Análise de equações estruturais: Fundamentos teóricos, software \& aplicações [Analysis of structural equations: Theoretical foundations, software \& applications]. Lisboa, Portugal: ReportNumber.

Maroco, J., \& Garcia-Marques, T. (2006). Qual a fiabilidade do alfa de Cronbach? Questões antigas e soluções modernas? [How reliableis Cronbach's alpha? Old issues and modern solutions?]. Laboratório de Psicologia, 4(1), 65-90. Retrieved from http://publicacoes.ispa.pt/index. $\mathrm{php} / \mathrm{lp} /$ article/viewFile/763/706

Mesquita Filho, M., Carvalho, C. R., \& Garcia, E. P. (2017). Fatores associados à ocorrência de acidentes de trânsito entre universitários [Factors associated with the occurrence of traffic accidents among university students]. Ciência \& Saúde, 10(2), 62-70. doi:10.15448/1983652X.2017.2.24205

Ministério da Saúde. Secretaria de Vigilância em Saúde. Departamento de Vigilância de Doenças e Agravos não Transmissíveis e Promoção da Saúde. (2015). Vigitel Brasil 2014: Vigilância de fatores de risco e proteção para doenças crônicas por inquérito telefônico. [Vigitel Brasil 2014: Surveillance of risk factors and protection for chronic diseases by telephone survey]. Brasília, DF: Author. Retrieved from http://bvsms.saude.gov.br/bvs/ publicacoes/vigitel_brasil_2014.pdf

Mola, R., Araújo, R. C., Oliveira, J. V. B., Cunha, S. B., Souza, G. F. F., Ribeiro, L. P., \& Pitangui, A. C. R. (2017). Association between the number of sexual partners and alcohol consumption among schoolchildren. Jornal de Pediatria, 93(2), 192-199. doi:10.1016/j.jped.2016.05.003

Oliveira, J. G., Araújo, J. L., Alchieri, J. C., Pereira, A. K. A. M., Nascimento, E. G. C., \& Vasconcelos, R. B. (2013). Conhecimento e comportamento sexual dos universitários diante a vulnerabilidade ao HIV/AIDS [Knowledge and sexual behavior of university students facing vulnerability to HIV / AIDS]. Revista Baiana de Saúde Pública, 37(3), 702-724. doi:10.22278/2318-2660.2013.v37.n3.a614

Oliveira-Campos, M., Nunes, M. L., Madeira, F. C., Santos, M. G., Bregmann, S. R., Malta, D. C., ... Barreto, S. M. (2014). Sexual behavior among Brazilian adolescents, National Adolescent School-based Health Survey (PeNSE 2012). Revista Brasileira de Epidemiologia, 17(Suppl. 1), 116-130. doi:10.1590/1809-4503201400050010
Raposo, J. C. S., Costa, A. C. Q., Valença, P. A. M., Zarzar, P. M., Diniz, A. S., Colares, V., \& Franca, C. (2017). Binge drinking and illicit drug use among adolescent students. Revista de Saúde Pública, 51, 83. doi:10.11606/ s1518-8787.2017051006863

Rosenbaum, J. E. (2009). Truth or consequences: The intertemporal consistency of adolescent self-report on the Youth Risk Behavior Survey. American Journal of Epidemiology, 169(11), 1388-1397. doi:10.1093/aje/kwp049

Sales, W. B., Caveião, C., Visentin, A., Mocelin, D., Costa, P. M., \& Simm, E. B. (2016). Comportamento sexual de risco e conhecimento sobre IST/SIDA em universitários da saúde [Risky sexual behavior and knowledge of STIs/AIDS among university health student]. Revista de Enfermagem Referência, 4(10), 19-27. doi:10.12707/RIV16019

Santos, O. T., Silva, I., \& Meneses, R. (2010). Estudo de fidelidade teste-reteste da adaptação do YRBS para Portugal [Test-retest reliability study of the yrbs adaptation for / in Portugal]. Psicologia, Educação e Cultura, 14(2), 301-318. Retrieved from https:/comum. rcaap.pt/bitstream/10400.26/5272/1/2010_PEC_2.pdf

Shrout, P. E., \& Fleiss, J. L. (1979). Intraclass correlations: Uses in assessing rater reliability. Psychological Bulletin, 86(2), 420-428. doi:10.1037//0033-2909.86.2.420

Silva, E. C., \& Tucci, A. M. (2016). Padrão de consumo de álcool em estudantes universitários (calouros) e diferença entre os gêneros [Pattern of alcohol consumption in college students (freshmen) and gender diferences]. Temas em Psicologia, 24(1), 313-323. doi:10.9788/TP2016.1-21

Teixeira, M. (2009). YRBS-C: Tradução, adaptação transcultural e propriedades psicométricas [YRBS-C: Translation, cross-cultural adaptation and psychometric properties] (Master's thesis). Universidade Estadual de Londrina, Londrina, PR. Retrieved from http:/www. dominiopublico.gov.br/pesquisa/DetalheObraForm. do?select_action $=\&$ co_obra $=178984$

Wang, M., Yi, J., Cai, L., Hu, M., Zhu, X., Yao, S., \& Auerbach, R. P. (2012). Development and psychometric properties of the health-risk behavior inventory for Chinese adolescents. BMC Medical Research Methodology, 12, 94. doi:10.1186/1471-2288-12-94

World Health Organization. (2009). Global school-based student health survey (GSHS). Geneva, Switzerland: Author. Retrieved from http://www.who.int/ncds/ surveillance/gshs/en/

Zullig, K. J., Pun, S., Patton, J. M., \& Ubbes, V. A. (2006). Reliability of the 2005 middle school Youth Risk Behavior Survey. Journal of Adolescent Health, 39(6), 856-860. doi:10.1016/j.jadohealth.2006.07.008 
Celina Aparecida Gonçalves Lima is a Professor of the Universidade Estadual de Montes Claros, Montes Claros-MG, Brazil.

Maria de Fatima de Matos Maia is a Professor of the Universidade Estadual de Montes Claros, Montes Claros-MG, Brazil.

Maria Fernanda Santos Figueiredo Brito is a Professor of the Universidade Estadual de Montes Claros, Montes Claros-MG, Brazil.

Lucineia de Pinho is a Professor of the Universidade Estadual de Montes Claros, Montes Claros-MG, Brazil.

Marise Fagundes Silveira is a Professor of the Universidade Estadual de Montes Claros, Montes Claros-MG, Brazil.

Authors' Contribution:

All of the authors made substantial contributions to the conception and design of this study, to data analysis and interpretation, and to the manuscript revision and approval of the final version. All authors assume public responsibility for the content of this manuscript.

Received: Dec. 05, 2017

1st Revision: Apr. 07, 2018

2nd Revision: Jul. 10, 2018

Approved: Jul. 27, 2018

How to cite this article:

Lima, C. A. G., Maia, M. F. M., Brito, M. F. S. F., Pinho, L., \& Silveira, M.F.(2020). Psychometric properties of the Youth Risk Behavior Survey - (YRBS) instrument in brazilian college students. Paidéia (Ribeirão Preto), 30, e3006. doi:http://dx.doi.org/10.1590/1982-4327e3006 


\section{Appendix}

Items of the Youth Risk Behavior Survey (YRBS) Instrument

\begin{tabular}{|c|c|c|}
\hline Domain/Item & Likert scale & kappa \\
\hline \multicolumn{3}{|l|}{ Personal safety } \\
\hline How often do you wear a seat belt when riding in a car driven by someone else? & $1-5$ & 0.58 \\
\hline How often do you wear a seat belt when driving a car? & $0-5$ & 0.78 \\
\hline During the past 12 months, how many times did you ride a motorcycle? & $0-4$ & 0.66 \\
\hline When you rode a motorcycle during the past 12 months, how often did you wear a helmet? & $0-5$ & 0.48 \\
\hline During the past 12 months, how many times did you ride a bicycle? & $0-4$ & 0.64 \\
\hline When you rode a bicycle during the past 12 months, how often did you wear a helmet? & $0-5$ & 0.57 \\
\hline During the past 12 months, how many times did you go boating or swimming? & $0-4$ & 0.79 \\
\hline When you went boating or swimming during the past 12 months, how often did you drink alcohol? & $0-5$ & 0.58 \\
\hline $\begin{array}{l}\text { During the past } 30 \text { days, how many times did you ride in a car or other vehicle driven by someone who had been } \\
\text { drinking alcohol? }\end{array}$ & $1-5$ & 0.73 \\
\hline $\begin{array}{l}\text { During the past } 30 \text { days, how many times did you drive a car or other vehicle when you had been drinking } \\
\text { alcohol? }\end{array}$ & $1-5$ & 0.74 \\
\hline \multicolumn{3}{|l|}{ Violence } \\
\hline $\begin{array}{l}\text { During the past } 30 \text { days, on how many days did you carry a weapon such as a gun, knife, or club? Do not count } \\
\text { carrying a weapon as part of your job. }\end{array}$ & $1-5$ & 0.65 \\
\hline During the past 30 days, on how many days did you carry a gun? Do not count carrying a gun as part of your job. & $1-5$ & 0.66 \\
\hline During the past 12 months, how many times were you in a physical fight? & $1-8$ & 0.42 \\
\hline During the past 12 months, with whom did you fight? & $0-5$ & 0.39 \\
\hline $\begin{array}{l}\text { During the past } 12 \text { months, how many times were you in a physical fight in which you were injured and had to be } \\
\text { treated by a doctor or nurse? }\end{array}$ & $1-6$ & 0.00 \\
\hline \multicolumn{3}{|l|}{ Suicide intent } \\
\hline During the past 12 months, did you ever seriously consider attempting suicide? & $1-2 *$ & 0.34 \\
\hline During the past 12 months, did you make a plan about how you would attempt suicide? & $1-2^{*}$ & 1 \\
\hline During the past 12 months, how many times did you actually attempt suicide? & $1-5$ & 1 \\
\hline $\begin{array}{l}\text { If you attempted suicide during the past } 12 \text { months, did any attempt result in an injury, poisoning, or overdose that } \\
\text { had to be treated by a doctor or nurse? }\end{array}$ & $0-2$ & 0.00 \\
\hline \multicolumn{3}{|l|}{ Tobbaco use } \\
\hline Have you ever tried cigarette smoking, even one or two puffs? & $1-2 *$ & 0.73 \\
\hline
\end{tabular}

\begin{tabular}{|c|c|c|}
\hline Domain/Item & Likert scale & kappa \\
\hline How old were you when you smoked a whole cigarette for the first? & $0-7$ & 0.84 \\
\hline During the past 30 days, on how many days did you smoke cigarettes? & $1-7$ & 0.87 \\
\hline During the past 30 days, on the days you smoked, how many cigarettes did you smoke per day? & $0-6$ & 0.71 \\
\hline Have you ever smoked cigarettes regularly, that is, at least one cigarette every day for 30 days? & $1-2 *$ & 0.00 \\
\hline $\begin{array}{l}\text { How old were you when you first started smoking cigarettes regularly (at least one cigarette every day for } 30 \\
\text { days)? }\end{array}$ & $0-7$ & 0.66 \\
\hline Have you ever tried to quit smoking cigarettes? & $1-2^{*}$ & 0.64 \\
\hline $\begin{array}{l}\text { During the past } 30 \text { days, on how many days did you use chewing tobacco or snuff, such as Redman, Levi } \\
\text { Garrett, Beechnut, Skoal, Skoal Bandits, or Copenhagen? }\end{array}$ & $1-7$ & 1 \\
\hline \multicolumn{3}{|l|}{ Alcoholic drink consumption } \\
\hline How old were you when you had your first drink of alcohol other than a few sips? & $0-7$ & 0.79 \\
\hline During the past 30 days, on how many days did you have at least one drink of alcohol? & $1-7$ & 0.76 \\
\hline $\begin{array}{l}\text { During the past } 30 \text { days, on how many days did you have } 5 \text { or more drinks of alcohol in a row, that is, within a } \\
\text { couple of hours? }\end{array}$ & $1-7$ & 0.83 \\
\hline
\end{tabular}




\begin{tabular}{|c|c|c|}
\hline Domain/Item & Likert scale & kappa \\
\hline \multicolumn{3}{|l|}{ Marijuana use } \\
\hline During your life, how many times have you used marijuana? & $1-7$ & 0.89 \\
\hline How old were you when you tried marijuana for the first time? & $0-7$ & 0.89 \\
\hline During the past 30 days, how many times did you use marijuana? & $1-6$ & -0.01 \\
\hline \multicolumn{3}{|l|}{ Other drugs } \\
\hline During your life, how many times have you used any form of cocaine, including powder, crack, or freebase? & $1-7$ & 0.85 \\
\hline How old were you when you tried any form of cocaine, including powder, rack, or freebase, for the first time? & $0-7$ & 0.66 \\
\hline $\begin{array}{l}\text { During the past } 30 \text { days, how many times did you use any form of cocaine, including powder, crack, or } \\
\text { freebase? }\end{array}$ & $1-6$ & 1 \\
\hline During your life, how many times have you used the crack or freebase forms of cocaine? & $1-7$ & 1 \\
\hline $\begin{array}{l}\text { During your life, how many times have you sniffed glue, or breathed the contents of aerosol spray cans, or } \\
\text { inhaled any paints or sprays to get high? }\end{array}$ & $1-7$ & 0.43 \\
\hline During your life, how many times have you taken steroid pills or shots without a doctor's prescription? & $1-7$ & 1 \\
\hline $\begin{array}{l}\text { During your life, how many times have you used any other type of illegal drug, such as LSD, PCP, ecstasy, } \\
\text { mushrooms, speed, ice, or heroin? }\end{array}$ & $1-7$ & 0.79 \\
\hline $\begin{array}{l}\text { During the past } 30 \text { days, how many times have you used any other type of illegal drug, such as LSD, PCP, } \\
\text { ecstasy, mushrooms, speed, ice, or heroin? }\end{array}$ & $1-6$ & 1 \\
\hline During the past 30 days, how many times have you used any illegal drug in combination with drinking alcohol? & $1-6$ & 0.00 \\
\hline
\end{tabular}

\begin{tabular}{|c|c|c|}
\hline Domain/Item & Likert scale & kappa \\
\hline During your life, how many times have you used a needle to inject any illegal drug into your body? & $1-3$ & 1 \\
\hline \multicolumn{3}{|l|}{ Sexual activity } \\
\hline How old were you when you had sexual intercourse for the first time? & $0-7$ & 0.94 \\
\hline During your life, with how many females have you had sexual intercourse? & $0-6$ & 0.94 \\
\hline During the past 3 months, with how many females have you had sexual intercourse & $0-7$ & 0.94 \\
\hline During your life, with how many males have you had sexual intercourse? & $0-6$ & 1 \\
\hline During the past 3 months, with how many males have you had sexual intercourse & $0-7$ & 0.94 \\
\hline During the past 30 days, how many times did you have sexual intercourse? & $1-6$ & 0.78 \\
\hline During the past 30 days, how often did you or your partner use a condom? & $0-5$ & 0.82 \\
\hline The last time you had sexual intercourse, did you or your partner use a condom? & $0-2$ & 0.73 \\
\hline Did you drink alcohol or use drugs before you had sexual intercourse the last time? & $0-2$ & 0.45 \\
\hline The last time you had sexual intercourse, what method did you or your partner use to prevent pregnancy? & $0-7$ & 0.87 \\
\hline How many times have you been pregnant or gotten someone pregnant? & $0-3$ & 0.88 \\
\hline During your life, have you ever been forced to have sexual intercourse against your will? & $1-2^{*}$ & 1 \\
\hline How old were you the first time you were forced to have sexual intercourse against your will? & $0-8$ & 1 \\
\hline How old were you the last time you were forced to have sexual intercourse against your will? & $0-8$ & 0.85 \\
\hline Have you ever had your blood tested for the AIDS virus/HIV infection? & $1-2^{*}$ & 0.94 \\
\hline \multicolumn{3}{|l|}{ Body weight } \\
\hline How do you describe your weight? & $1-5$ & 0.84 \\
\hline Which of the following are you trying to do about your weight? & $1-4$ & 0.51 \\
\hline During the past 30 days, did you diet to lose weight or to keep from gaining weight? & $1-2 *$ & 0.54 \\
\hline During the past 30 days, did you exercise to lose weight or to keep from gaining weight? & $1-2^{*}$ & 0.51 \\
\hline During the past 30 days, did you vomit or take laxatives to lose weight or to keep from gaining weight? & $1-2^{*}$ & 0.26 \\
\hline During the past 30 days, did you take diet pills to lose weight or to keep from gaining weight? & $1-2^{*}$ & 0.69 \\
\hline What is your height? (In inches.) & - & - \\
\hline What is your weight? (In pounds.) & - & - \\
\hline \multicolumn{3}{|l|}{ Feeding } \\
\hline Yesterday, how many times did you eat fruit? & $1-4$ & 0.16 \\
\hline Yesterday, how many times did you drink fruit juice? & $1-4$ & 0,16 \\
\hline
\end{tabular}


Domain/Item

Likert scale

Yesterday, how many times did you eat green salad?

1-4 0.52

Yesterday, how many times did you eat cooked vegetables?

$1-4 \quad 0.33$

Yesterday, how many times did you eat hamburger, hot dogs, or sausage?

$1-4 \quad 0.34$

Yesterday, how many times did you eat French fries or potato chips?

$1-4 \quad 0.24$

Yesterday, how many times did you eat cookies, doughnuts, pie, or cake?

$1-4 \quad 0.42$

Physical activity

On how many of the past 7 days did you exercise or participate in sports activities for at least 20 minutes that made you sweat and breathe hard, such as basketball, jogging, swimming laps, tennis, fast bicycling, or similar aerobic activities?

On how many of the past 7 days did you do stretching exercises, such as toe touching, knee bending, or leg stretching?

On how many of the past 7 days did you do exercises to strengthen or tone your muscles, such as push-ups, situps, or weight lifting?

On how many of the past 7 days did you walk or bicycle for at least 30 minutes at a time? (Include walking or bicycling to or from class or work.)

During this school year, on how many college sports teams (intramural or extramural) did you participate?

$1-8$

0.51

*Note. Dichotomous items
$1-8$

0.54

$1-8$

0.74

1-8

0.44

1-4 